International Journal of Public Administration

\title{
Public-Private Partnership in Tunisia: Enfidha Airport Assessment of an Infrastructure Achievement
}

\section{Nada Abdelkader Benmansour}

To cite this article: Nada Abdelkader Benmansour (2016) Public-Private Partnership in Tunisia: Enfidha Airport Assessment of an Infrastructure Achievement, International Journal of Public Administration, 39:7, 552-562, DOI: 10.1080/01900692.2015.1004087

To link to this article: http://dx.doi.org/10.1080/01900692.2015.1004087

Published online: 20 Jan 2016.

Submit your article to this journal $\square$

Џll Article views: 55

Q View related articles $\square$

View Crossmark data ¿ 


\title{
Public-Private Partnership in Tunisia: Enfidha Airport Assessment of an Infrastructure Achievement
}

\author{
Nada Abdelkader Benmansour \\ Research Department, FIKRA, Doha, Qatar
}

\begin{abstract}
One of the largest recent private-sector investments and the first airport private-sector concession in the Maghreb is Enfidha Airport, a key factor in the success of the Tunisian Government's publicprivate partnership (PPP) strategy. However, since Tunisia's Jasmine Revolution, political and social turmoil is sweeping the country and worsening the economic indicators. This article aims to assess this PPP infrastructure, allowing us to determine if it is profitable in the long term and contributes therefore to the economic growth. The case study reveals the key role of the economic, social, and political environment in Tunisia, the dawn of the Arab Spring.
\end{abstract}

\section{KEYWORDS}

Airport; arab spring;

infrastructure; public-private partnership; Tunisia

\section{Introduction}

Public-private partnerships (PPPs) have emerged among a wide contemporary move of reforms which aim to involve the private sector more deeply in public service provision (Osborne, 2000). Indeed, faced with pressure to reduce public-sector debt and, at the same time, expand and improve public facilities, governments have invited private-sector entities to enter into long-term contractual agreements (Grimsey \& Lewis, 2002). They also became result oriented, performance based, and privatized. Basically, concepts of governance evolved during the last two decades from a traditional, authoritarian, bureaucratic governance toward a neoliberal ideology—and its critique of the supposed monopolistic and bureaucratic inefficiencies-based on market approaches, "post-bureaucratic forms," and "government by contract" (Kirkpatrick \& Lucio, 1996; Osborne \& Gaebler, 1992). Those reforms are referred to as "New Public Management" and their key tenets emanate from the public choice theory, principal-agent theory, and transaction cost theory (Arrow, 1985; Buchanan \& Tolluck, 1962; Downs, 1967; Niskanen, 1971; Williamson, 1985).

Within Middle East North Africa (MENA) countries, the last few decades witnessed a major shift in the economic policies-from a central planning and an important public sector, toward an open market policy associated with a growing effort of privatization (UNEVOC Centers, 2006). In this context, PPPs are becoming a classical way to implement infrastructure and public procurement in many sectors like transport, defense, schools, hospitals, and jails (Esposito, 2010).

In Tunisia, PPPs have been for many years a part of a general policy of modernization of the public sector. One of the largest private-sector investments in the country, with total costs of $\$ 605$ million USD, and the first airport private-sector concession in the Maghreb region (IFC, 2008), is Enfidha Airport.

Tunisia's "Jasmine Revolution" is the first popular uprising to topple an established government in the Middle East and North Africa since the Iranian revolution of 1979. It is also the spark that inspired other revolutions in the region. Since then, the country is adrift economically, socially, and politically and the various after revolution's governments failed in implementing political, institutional, or social reforms that might attract international investors or increase opportunities for project finance and infrastructure development in general.

This article provides an analysis of Enfidha Airport PPP since few evaluations have been realized about its implementation and evaluation. The analysis is a case study approach based on documents published by the African Development Bank (AfDB) and the International Finance Corporation (IFC) and information in the public domain. The key question under scrutiny is the extent in which PPP can face Tunisian infrastructure challenges and so far participate to improve the efficiency of the public service 
delivery. The article presents, first, PPP in MENA countries and then analyzes the specific case of Enfidha Airport PPP.

\section{Definition of public-private partnerships}

A PPP is an agreement between the government and one or more private entities for the delivery of a service. Under this type of agreement, the private partner delivers the service in a way that meets both the government's service delivery objectives and the private partner's profit objectives.

Theoretical literature highlights at least threefold advantages related to PPPs: budgetary advantage, managerial impetus, and technological breakthrough (Marty, 2008). The budgetary advantage consists in achieving important programs without supporting the burden of inherent expenses which is of a high importance in the context of economic crisis. The second advantage is taking benefit from cost and scheduling control which is related to the contract conditions. The third advantage is that PPP allows the public sector access to private-sector's skills and innovation and technological expertise. Thus, this should lead to a better quantity and quality for the delivered service (Estache et al., 2009).

The private counterpart can also reach some benefits from the PPP contract like to secure its activities through a long-term contract and to develop them to high added value activities (Marty, 2008).

Besides, PPPs involve contracting between government and the private sector under conditions of imperfect information. Consequently, two main strands of economic theory-principal-agent theory and transaction costs analysis-are very relevant to an understanding of the PPPs.

The principal-agent theory (agency theory) formalizes assumptions about the distribution of property rights and information while writing contracts that define organizations. In particular, it focuses on the relationship between principals and agents who exercise authority on behalf of organizations. The theory argues that principals must solve two basic tasks in choosing and controlling their agents. First, they have to select the best agents, whether employees or contractors, and create motivations for them to behave as desired. Second, they have to monitor the behavior of their agents to ensure that they are performing as agreed (Ayee, 2005). A problem arises when the parties' goals conflict or when it is difficult or expensive for the principal to check what the agent is actually doing. Information asymmetry here introduces an adverse selection and a moral hazard problem (Arrow, 1985).
Transaction costs arise from the cost of seeking out buyers and sellers and arranging, policing, and enforcing agreements or contracts in a world of imperfect information. The idea has been popularized by Oliver Williamson since the 1960s (Williamson, 1975, 1985). This theory views the parties attempting to engage in exchange as contracting both the terms of the exchange and its execution. A contract should also take into account all the expenses made in order to reach that contract, whether they are personal or social. The contracting process can be very expensive because it includes not only the structuring, monitoring, bonding, and residual loss costs of the principal-agent problem, but it also includes the negotiation's costs (Kettl \& Milward, 1996).

Consequently, PPPs may incur high transaction costs, especially where there is no culture of PPPs or little knowledge of the process. When there is government provision, production costs will determine the total social costs, and considering the fact that they are internalized, transaction costs are likely to be low. However, managerial inefficiency may mean high production costs, it is evident that large government infrastructure projects have often been way over the budget. PPPs can lower production costs because of competitive pressures that eliminate managerial inefficiency. Economies of scale may mean that private-sector firms have lower production costs (Williamson, 1975). But, private production can raise transaction costs because government has to negotiate with suppliers who have their own incentives (Vining \& Boardman, 2008). The effectiveness of the alignment depends on a sufficient transfer of risk to the private partners (which may include the operators and the financers) (OECD, 2008). Indeed, the distribution of risk and responsibilities between the two partners is the crucial point of this contractual agreement. Each risk must be allocated to the party who can manage it at the minimal cost. The private partner will be remunerated from payments made by the user of the service or by direct payments from the public body based on the service provided, its availability and different contractual quality, and performance indicators (Marty and Voisin, 2006).

\section{Classification of public-private partnerships}

The most cited, and obviously the most straightforward classification of PPPs, situates different partnership variants on a range that reflects the extent to which risk is being transferred from the public to the private partner. The range runs from a contribution contract with minimal risk transfer to partnerships with maximum risk transfer (Estache et al., 2009). In between the 
two are several possible combinations of functions the private sector can undertake: design, build, finance, operate, maintain, own, transfer, lease, develop, and buy (Allan, 1999).

The main different types are:

- Design-Build (DB): Under this model, the government contracts with a private partner to design and build a facility in accordance with the requirements set by the government. After completing the facility, the government assumes responsibility for operating and maintaining the facility. This method of procurement is also referred to as Build-Transfer (BT).

- Design-Build-Maintain (DBM): This model is similar to DB except that the private sector also maintains the facility. The public sector retains responsibility for operations.

- Design-Build-Operate (DBO): Under this model, the private sector designs and builds a facility. Once the facility is completed, the title for the new facility is transferred to the public sector, while the private sector operates the facility for a specified period. This procurement model is also referred to as Build-Transfer-Operate (BTO).

- Design-Build-Operate-Maintain (DBOM): This model combines the responsibilities of $\mathrm{DB}$ procurements with the operations and maintenance of a facility for a specified period by a privatesector partner. At the end of that period, the operation of the facility is transferred back to the public sector. This method of procurement is also referred to as Build-Operate-Transfer (BOT).

- Build-Own-Operate-Transfer (BOOT): The government grants a franchise to a private partner to finance, design, build, and operate a facility for a specific period of time. Ownership of the facility is transferred back to the public sector at the end of that period.

- Build-Own-Operate (BOO): The government grants the right to finance, design, build, operate, and maintain a project to a private entity, which retains ownership of the project. The private entity is not required to transfer the facility back to the government.

- Design-Build-Finance-Operate/Maintain (DBFO, DBFM, or DBFO/M): Under this model, the private sector designs, builds, finances, operates, and/or maintains a new facility under a longterm lease. At the end of the lease term, the facility is transferred to the public sector. In some countries, DBFO/M covers both $\mathrm{BOO}$ and BOOT.
Even if governments typically aim at certain objectives when developing infrastructure projects, the most common reason for those partnerships is the financial-economic motive, the limited financial capacity of governments for investments, which makes the prospects of private-sector cofinancing very important (Farazmand, 1999). Then, it is left to them to find the right equilibrium between the model of delivery that best addresses those objectives and the one who will be sufficiently attractive for private partners.

\section{Critical success factors for PPP}

Many studies have developed differing lists of critical success factors for PPP, and similarities occur among them.

Farazmand (2004) established two set of conditions for building and sustaining effective partnerships: (1) primary, start-up conditions and (2) process conditions. The primary conditions are interdependence and convergence of objectives and accommodation of goals. The process conditions are: mutual trust and good faith in the focused areas of partnership; recognition of limitations of each party; clarification-and recording-of objectives and strategies; phasing aims of partnership projects at the verifiable and measurable details; creating conflict regulations and conflict resolution mechanisms; focusing on issues, problems, and objectives/goals of partnerships; identifying and spelling out legal issues and procedures; protection of third parties' interests and rights; adequate support and control facilities that enhance partnerships; internal and external coordination through formal and informal processes, networks, and mechanisms; appropriate and adequate organizational arrangements, management, and skills for policy development, analysis, and implementation/administration in partnership-based governance.

Li, Akintoye, Edwards, \& Hardcastle (2005) identified five principal success factor groupings that underlie project procurement: project implementability, government guarantee, favorable economic conditions, and available financial market.

Qiao, Wang, Tiong, and Chan (2001) developed eight independent critical success factors in BOT projects in China: appropriate project identification; attractive financial package; acceptable toll/tariff levels; reasonable risk allocation; selection of suitable subcontractors; management control; technology transfer; and stable political and economic situation.

\section{Public-private partnerships in MENA countries}

Infrastructure development is proven to be critical for economic development and poverty reduction in 
developing countries, and improved infrastructure services can help address various development challenges. However, governments face major issues in ensuring efficient service provision and meet the growing demand for infrastructure services mainly due to lack of financial resources. PPPs represent an opportunity for the MENA countries as far as they often show high deficit in infrastructure requirements, while a low quality is often associated with public service performance. Thus, PPPs can simultaneously accelerate improvements to public infrastructure, service efficiency, and service quality which are necessary for economic growth. PPPs can thus represent a solution to government's economic reform agenda and strategy to increase private-sector involvement in public services through leveraging private spending against public service budgets (ACWUA, 2010).

In developing countries, contracting out was introduced in the mid-1980s when governments begin privatizing public enterprises. Policies were adopted to solve the problem of lack of governmental managerial capacity, and also to stop the continued dependence of state enterprises on state subsidies (OECD, 2009). According to Deloitte, in Africa, between 1990 and 2004 , around $14 \%$ of public-sector infrastructure was provided through a PPP, the most common sectors being water, energy, and transport (Deloitte Research, 2006). In the MENA region, the annual investment commitments in 2004-2008 were three times those in 1996-2000, which represented one of the fastest regional growth rates in private participation in infrastructure (World Bank, 2008). This growing interest from private investors can be explained by the important demand for infrastructure and good expectations for cost recovery in the region. Most of the recent growth in private participation has been in telecommunications, but it is also increasing in energy, transport, irrigation, and solid waste management (World Bank, 2008). However, MENA countries still have difficulty in attracting private partners. In North Africa, private investments remain at a low level (Chédor, Teulon, \& Veil-Zarda, 2011).

Now, and since the Arab Spring, political turmoil is sweeping the MENA region and generating political and economic issues across the region. Unemployment has risen, economic growth rates have fallen, and fiscal deficits and government debt levels have grown.

Thus, the Arab Spring, which was generated by weak infrastructure services, is becoming the scene of a chaotic political and economic situation which is now slowing down-and even stopping-the contribution of the private sector in financing expansion or improvement of infrastructure developments. Nevertheless, it is obvious that offering general access to adequate infrastructure services remains crucial to impulse economic development and growth and to provide jobs in the region.

In Tunisia, the Revolution, which successfully ousted longtime President Zine El Abidine Ben Ali, consisted of a series of street demonstrations, in January 2011, following the self-immolation of Mohamed Bouazizi on December, 17, 2011 (Timeline: Tunisia's uprising, 2011). The demonstrations were an expression of citizens' frustration over economic issues like unemployment as well as lack of political freedoms (Mohyeldin, 2011; Sadiki, 2010). Since then, political turmoil is sweeping the country and is leading to worsening economic indicators. The country, which has traditionally had great success in attracting foreign direct investment and local project investment, became less attractive to investors who are less confident and are therefore less willing to launch new projects or to develop ongoing ventures.

In this context, this study aims to discuss the potential of the Enfidha Airport PPP project. The question asked is: how far is PPP useful to face infrastructure challenges and so far to contribute to improve efficiency of the public service delivery.

\section{PPP's practice in tunisia}

Tunisia, with an estimated population of just over 10.4 million, has a diverse economy, mostly in the agricultural, mining, tourism, and manufacturing sectors. Real growth, which averaged almost $5 \%$ over the past decade (official rate), declined to $4.6 \%$ in 2008 and to $3 \%-4 \%$ in $2009 / 2010$ because of economic contraction and slowing of import demand in Europe, Tunisia's largest export market. Though, till 2010, Tunisia was ranked among the most growing economies in Africa (African Arab Bank of Development's reports, 2012-2013). The January 2011 Tunisian revolution has had a negative impact on the short-term economic situation, mainly due to the decrease of tourism and foreign direct investment. Gross Domestic Product (GDP) is slowing down, and the rate of youth unemployment-particularly youth with graduate degrees-reached unprecedented levels since the revolution. The social unrest and political turmoil that overwhelmed Tunisia indicate that key social and development challenges had not been addressed.

Economic emergency plans and institutional and structural reforms have been announced by the different interim governments, but as the political turmoil continues, the economic situation is still critical and 
private and foreign investors remain suspicious. Local investments are oriented to real estate and consumption instead of productive projects which require political stability by a democratic transition process.

Access to good-quality infrastructure services is crucial to Tunisian economy, and in order to bring new investments to the country's infrastructure sectors, the government asked PPIAF for support in developing "a comprehensive strategy for increasing the private provision of infrastructure and updating the legal, regulatory, and institutional framework to support sustainable public-private partnerships in infrastructure" (World Bank, 2008).

Since then, the government tried to promote PPPs. He accepted the need to separate regulatory and operating functions in port and airport sectors and the need to broaden private-sector participation beyond subcontracting and build-operate-transfer contracts in water and sanitation. In April 2008, the government adopted a framework law on concessions, in order to make the country more attractive to private operators (World Bank, 2008, 2011).

Actually, PPP has been a part of a general policy of the Tunisian administrative reform and the legislative and regulatory framework has been developed in order to facilitate PPP development (Araujo \& Sutherland, 2010). According to the World Bank database, in 2007 there were already seven PPP contracts in Tunisia (World Bank, 2007): four contracts within energy sector (electricity and natural gas), two in telecommunications, and one within airport infrastructure. "The cumulative amount of investment in the telecommunications sector amounted to 3.17 billion USD between 1990 and 2007. For the airport, gas and electricity projects, the amounts of private investment were respectively USD 840, USD 657 and USD 291 million" (World Bank, 2007).

Other PPP projects are in progress in Tunisia including a project for a new deep-water port at Enfidha, in the framework of a BOT. This project is similar to many operations in progress in the MENA region: in Morocco (Tangier), in Egypt (Damiette, Ain Sukna, Alexandria), and in Jordan (Aqaba).

\section{Enfidha airport-lessons learned}

In developing countries, governments are being aware of the benefit of involving the private sector in managing and financing airports to improve service provision. Indeed, an efficient and effective aviation infrastructure is crucial to development insofar as airports represent essential links to economic development through flows of human capital, commerce, and tourism.

In Tunisia, infrastructure projects have always been achieved by the government and Enfidha Airport, located at an emerging town distant at some $100 \mathrm{~km}$ south of Tunis (the capital) and $60 \mathrm{~km}$ from the Monastir Airport, is therefore the first example of PPP infrastructure in the country and of an airport concession in the Maghreb region. The project is consistent with the 10th governmental Economic and Social Development Plan for 2007-2011 which aims to support PPPs (Ministry of Transportation, 2014).

Since important touristic and industrial development projects were planned, modernization and expansion of airport infrastructure became essential. The main Tunisian airports, located at the north of the country, were either already saturated (Monastir Airport), or near to reach saturation point (TunisCarthage Airport). They shuttle to the main touristic Mediterranean areas of Sousse, Hammamet, and Monastir. A new airport was necessary and the private-sector's participation served as a catalyst in the project's design and implementation. Instead of bearing the entire cost and dealing with the project risks, Tunisian authorities decided to rely on private capital and the private-sector's managerial ability and state-ofthe-art technology. This has paid off handsomely, resulting in the construction of a modern, spacious, comfortable, and efficient airport.

The contract is a 40 years concession and consists of two linked concessions. The first concession is for build, operate, and transfer (BOT) of the new airport at Enfidha and the second one is for the operation and upgrade of the existing Monastir International Airport (4.2 million passengers in 2006) (IFC, 2008). The project has been awarded to TAV Airports Holding, an Istanbul-based Turkish company specialized in airports construction, operation, and management. The company is managing four airports in Turkey (Istanbul Ataturk, Ankara Esenboga, Antalya Gazipasa, and Izmir Adnen Menderes), two in Georgia (Tbilissi and Batumi), two in Macedonia (Skopje and Ohrid), and one in Saudia Arabia (Medina).

In 2008, TAV Tunisia Ltd, a subsidiary of TAV Airports, elaborated a financial plan with International Finance Corporation (IFC), branch of the World Bank, and with many commercial banks. The African Development Bank (AfDB) was also contacted and participated with a 70 million Euros loan.

This project is a central element of Tunisia's growth strategy since, by expanding and mondernizing the airport infrastructure of Tunisia, it is expected to directly contribute to the success of the country's economic 
strategy which is built on two pillars (African Development Fund, 2008):

- Export-oriented industrialization, with a specialization in low-cost light manufacturing,

- Tourism development, with major efforts underway by the Government to enhance tourist arrival numbers and reposition Tunisia toward the higher end of the market.

The project complies with Tunisian's environmental regulations, particularly Decree $\mathrm{N}^{\circ} 91-362$ of March 1991, modified in July 2005, on Environment and Social Impact Assessment requirements, and with the international standards in project finance, the Equator Principles. The project also follows the IFC/World Bank Group best practices environmental standards. IFC's environmental and social due diligence indicates that the investment will have impacts which must be managed in a manner consistent with the following Performance Standards:

PS1: Social and Environmental Assessment and Management Systems

PS2: Labor and Working Conditions

PS3: Pollution Prevention and Abatement

PS4: Community Health Safety and Security

PS5: Land Acquisition and Involuntary Resettlement

PS6: Biodiversity Conservation and Sustainable Natural Resource Management

PS7: Cultural Heritage

The project is sustainable at the economic and financial levels and does not represent environmental threats. The project should contribute to impulse the national GDP and the global country competitiveness. During the project construction phase, which lasted 2 years, some 2200 direct full jobs were created. Close to $70 \%$ of project workers were locally recruited, while the rest were mainly Turkish expatriates. During the operation phase, some 1400 jobs were created. Employees at the airport said they were proud to be working at the Enfidha Airport as it offered them a good job and a competitive salary and spares them the pain of migrating to bigger cities or to Europe.

The project began in July 2007 and the first stage was achieved in October 2009. According to the airport management, Enfidha Airport reaches international performance levels. It has the capacity to handle some 4500 pieces of luggage per hour while respecting European airport security standards.

As few evaluations of PPP in Tunisia are achieved, this article aims to analyze the Enfidha Airport PPP. A case study approach is thus adopted as the research methodology based on documents published by AfDB, IFC, and information in the public domain.

The present article aims to assess Enfidha Airport PPP infrastructure achievement and to highlight some key elements related to its implementation in order to determine how profitable the project is and how it contributes to the country's economic growth. It points out three key aspects that emerge from this experience. First, the opportunity, for a developing country like Tunisia, to take profit from the private financial, technical, and managerial experience for an infrastructure development. Second, the importance of regulatory and legal framework. Third, a stable economic, political, and social environment as a critical external success factor.

\section{The opportunity to take profit from the private financial, technical, and managerial experience}

To support their economic activities, the infrastructures required by developing countries are those related to transportation, energy, water, and telecommunications. However, the need of high capital investment and of technology can be a stumbling block to infrastructure development and many developing countries cannot afford such development. This is what Farazmand (2004) refers to as primary start-up condition to build efficient partnerships: the interdependence and convergence of objectives. That means that no party-neither the State, nor the private partner-is capable alone of developing the project and the partnership will materialize the law of relative advantage. Convergence means that the objectives of the different parties in the partnership are connected or at least not incompatible.

In this context, the PPP of Enfidha Airport allowed the Tunisian government to take profit from a consortium of private financers. It also allowed to take profit from the building experience of TAV Holding and to experience new technologies. Then it allowed mobilizing experienced staff for which the private can provide higher salaries than public sector. Besides, public staff have been maintained and have taken profit from the know-how of the experienced private staff. The access to finances and to the experience in infrastructure building makes it possible to reach the construction of an airport within 2 years, which objective the government couldn't have reached by itself. And, according to the contract, the property will be transferred to the government (after 40 years of operating) without any investment. 


\section{The importance of regulatory and legal framework}

The role of the legal framework is to create a favorable environment to attract private financing and to implement checks and balances that will ensure that PPPs deliver their expected value to the public (Boyfield (1992), Stein (1995), Jones, Zamani, and Reehal (1996) and Finnerty (1996). Thus, setting an adequate regulatory and legal framework prior to implementing PPP contracts is clearly crucial and is amid major conditions for building and sustaining an effective partnership (Farazmand, 2004). According to the World Bank, "regulatory system should define clear rules for financial performance, provide practical experience to the staff responsible for their implementation, and provide assurance to the private sector that the regulatory system includes protection from expropriation, arbitration of commercial disputes, and respect for contract agreements. In turn, the regulatory system will increase benefits to the government by achieving better and more informed decision making, improved performance, and by raising efficiency and accountability" (The World Bank, 1994).

In this context, and in order to attract investors, the Tunisian government developed a legal adequate framework related to PPPs. This framework is divided into two major frameworks. The first one concerns concessions and is regulated by the law $\mathrm{N}^{\circ} 2008-23$ dated 01/04/2008. From 1998 to 2008, concessions are treated separately in accordance with laws, decrees, specifications, and ministerial orders. However, competition and transparency of the procedures have to be guaranteed and the creation of a legal framework related to concessions became necessary. The law $\mathrm{N}^{\circ}$ 2008-23 makes provision for the risk distribution between the co-contractors and fixes the procedures of the choice of the concessionaire. It stipulates that this choice can be performed (i) after direct negotiation or (ii) after a consultation if the invitation to tender doesn't lead to interesting results or (iii) if there is an emergency related to the continuity of the public service delivery by a given entity or (iv) if the contract can only be achieved by a given entity. This law authorizes foreigners to participate to concessions. The second one concerns privatization and is regulated by the law $\mathrm{N}^{\circ}$ 89-9 dated 01/02/1989 (concerning participations, companies, and publicly owned establishments).

The Tunisian experience highlights the importance, for PPPs, of good public regulations compatible with international investment conditions. Clear legal rules and their predictable application offer legal security to investors. This improves competition for contracts and reduces the risk premium required-two recurrent problems with PPPs. Indeed, the Tunisian legal framework for PPPs was completed in 2008 by a generally applicable law on concessions. The law was intended to clarify the legal framework and to unify practices and arrangements previously implemented at the specific level and governed by diverse preexisting laws. The law on concessions helped increase the attractiveness of investing in PPPs by providing all stakeholders with a clear and coherent legal framework. The law on concessions (the term used by the Tunisian law rather than PPP) emphasizes transparency during the tendering process. It introduces a procedure involving competitive consultation: allowing a first phase of competitive bidding based on an invitation to tender, followed by a second phase of negotiation.

In this context, Jaloul Ayed (former Tunisian finance minister, 2011) points out crucial issues to carry out PPPs. First, to develop an exhaustive regulatory framework, precise, securing, establishing basic rules, and stimulating private sector to participate. Second, to promote a Tunisian legal know-how to assist private agents in their negotiations with local government and to solve the problem of funding due to exchange risks. Indeed, it is demonstrated that the quality of legislative and regulatory frameworks-and the development of capacity within a public authority for selecting projects, guiding the selection phase, drawing up contracts, and monitoring their execution-are all vital in the efficient and successful use of PPPs in MENA countries (Araujo \& Sutherland, 2010).

The Tunisian experience shows the governmental impetus to build an adequate regulatory and legal PPP framework. This allowed attracting foreign private investors to apply to the airport tender and then, allowed TAV Holding to operate in the context of the BOT contract. Meanwhile, it shows some shortcomings like the need to develop a more adapted legal framework in order to be more attractive to private participation. And prior to this, it points out the need to increase public actors' awareness concerning PPPs.

\section{The importance of socioeconomic stable environment}

Tunisia, one of the more stable areas in the region, was however, the first Arab nation in the MENA region to protest against its dictatorial regime, in what became known as the Jasmine Revolution. Since then, Tunisia lives a phase of difficult transition, marked by economic turmoil and terrorist attacks. The political environment has been marked with political uncertainty especially since the assassination of opposition leader Chokri Belaid (Patriotic Democratic Front Leader) 
February 6, 2013, which was followed by a series of attacks across the country. Major opposition parties called for the resignation of the government and the dissolution of the National Constituent Assembly (ANC), which was scheduled to vote on the constitution and finalize the composition of the electoral authority and pass an electoral law. While social and economic issues remain at the core of Tunisian concerns, there was an increasing demand for government to limit policy-making to the passage of the new constitution and electoral law which were delayed beyond the 1-year commitment. Once the 1-year mark passed in October 2012, opposition parties began a series of protests to push for the completion of the process and elections by end December 2013.

As a consequence, Tunisia's economic growth slowed down since 2011 and unemployment rates among university graduates increased. Security concerns and weak economic performance in the European Union and Libya have dampened growth. GDP growth was only 2.7\% in Quarter (Q) 1, 2013, and 3.2\% in Q2 2013. Inflation had steadily increased, due to high food prices, since 2012 to peak at $6.5 \%$ in March 2013. It has since stabilized to $6 \%$ in recent months responding to tighter monetary policy by the Central Bank (The World Bank, 2014). Authorities estimated that during the recent upheavals between USD 5 and 8 billion (around 4\% GDP) were lost, tourism revenues have been seriously affected, key investments have been put on hold, and numerous jobs have been lost (African Development Bank, 2011).

The critical economic situation and the political turmoil have led to countless social movements through all the economic sectors which had consequently internal and external impacts on Enfidha Airport achievement. Indeed, local newspapers reported that either TAV blue collars were on strike or Enfidha neighborhood citizen were blocking workers' access to the airport.

Though, written human resource policy established by TAV follows all national laws with regard to minimum employment age and maximum work hours and allows freedom of association. Besides that, contractors whom TAV deals with are required to ensure their hiring and employment practices are consistent with national law and the requirements of Performance Standard 2: Labor and Working Conditions. TAV has a detailed Health and Safety Environment Plan which sets standards for occupational safety and work procedures for employees and contractors as well as training for employees and contractors on worker safety and emergency response has been conducted at Monastir and Enfidha. No layoff of workers has been done as a certain number of staff has been transferred from Monastir to Enfidha on an initial voluntary basis. Actually, many staff members have expressed a desire to work at the new airport as to experience the new modern work environment. A shuttle service has been set up to facilitate the movement of staff between their residences and the two airports $(30 \mathrm{~km}$ between Monastir and Enfidha). Finally, TAV employees absorbed from the Office de l'Aviation Civile et des Aéroports (OACA) as part of the privatization have retained all their rights as former OACA employees and have union representation to assist in the negotiation of all human resource-related issues.

Despite this disposal, strikes and social movements happened and generated many harmful consequences like delaying the work, the staff being many times unable to join their offices, and the loss of many flights and passengers as tour operators canceled their flights to Enfidha Airport, activity decreased as well as income. Borders entry number between 2010 and 2013 decreased by $9.2 \%$ (Tunisian Ministry of Tourism).

While it seems that TAV had to deal with unstable economic and political environment, many studies inclined toward identifying PPP success factors highlight the importance of the favorable economic and political conditions (Brown, Orr, \& Luo, 2006; Li et al., 2005; Qiao et al., 2001).

Dilami and Klein (1997) identify the importance of a stable and favorable macroeconomic environment for PPP project development both in developed and in developing countries, where the private sector can operate with confidence. Two critical success factors are involved: a stable macroeconomic conditions and a sound economic policy.

Regarding the role of the government during this critical transition, Sengupta (2006) argues that even though the private developer is expected to perform all development tasks under PPP, the public agencies may take on the role of the enabler by providing the enabling environment for the private partner to step in. Indeed, PPP should not imply less government but a different government role as the ultimate responsibility and accountability of the partnership rests on the shoulders of the government that has to be accountable to its people (Farazmand, 1999). This also refers to what Farazmand defines as a process condition for successful partnerships: accountability and protection of rights for all citizens that must be observed as some powerful groups might influence unfairly the policy agenda and or implementation (Farazmand, 2004). This is what happened for Enfidha PPP as OACA employees and citizens were causing delays due to their various strikes. By then, the Tunisian 
government was overwhelmed by the political, economical, and social situation prevailing after the Revolution and could not focus on Enfidha PPP and take the expected role of the enabler.

Also, according to Klijn and Teisman (2002), actors involved in PPP are likely to have different objectives and contrasting backgrounds which make cooperation as much challenging. Problems are generated by the fact that partnerships require many actors and that those actors are dependent on each other. The multiplicity of actors and their various and often conflicting perceptions, interests, and strategies make these games complex ones (Cohen, March, \& Olsen, 1972). Following this approach, the actors involved in Enfidha Airport PPP are various and have contrasting backgrounds and their expectations changed after the 2011's Revolution:

(i) TAV, the contracting company: focused on market share and profits before the Revolution and concerned by strikes, social movement, and political turmoil and the completion of the contract on time and budget after the Revolution,

(ii) OACA employees: focused on their well-being before Revolution and concerned by the improvement of their economic, social, and labor conditions after the Revolution,

(iii) National government: focused on policy interest before Revolution and concerned by social, economic, and political turmoil after the Revolution,

(iv) Citizens: focused on the success of the achievement on their region before Revolution and concerned by direct impact on their social and economic conditions after the Revolution,

(v) Banks: focused return on investment before the Revolution and concerned by the contractor's solvency and social, economic, and political conditions after the Revolution,

Today, the economic situation is very critical, the social situation is worrying, and people dissatisfaction is increasing. Economic growth is slowing down and not duly divided. Investment is at a very low level, and shortfall increases and unemployment is increasing.

Under these circumstances, the first Tunisian Parliamentary elections on October, 26, 2014, with the victory of the secular party Nidaa Touness, brought new hope. It can be viewed as a step toward real political change and democratization process as it materializes the liberalization of the political landscape and a dramatic rise in the levels of civil and political rights. Analysts described this election as a referendum on the Islamist-led coalition's stormy 2 years in office and punishment for a poor economic performance and unfulfilled expectations of the revolution. Numerous opportunities are available and the country can improve its growth once the period of unrest and revolution begins to decline. Investors in ongoing and new development projects need to remain positive as the region settles and becomes an investor's market (Orsi, 2011). The future is optimistic for Tunisia and many authors define the country as "the only-Arab Spring country- success story." However, serious challenges remain before the full potential presented by the Tunisian Revolution can be realized. Besides the political and security-related challenges that need to be navigated as the country moves toward presidential elections, the economy and fiscal balances will be under pressure as a result of the drop in economic activity that surrounded in the wake of the Revolution. Moreover, the underlying social discontentment that drove the Tunisian Revolution-notably youth unemployment, particularly among young graduates, and regional disenfranchisement-remains (African Development Bank, 2011). The main battle is political. Tunisia is engaged in its fight for democracy. This first Arab Spring country can become the first sustainable success in the region.

\section{Conclusion}

Like many developing countries, Tunisian government faces fiscal pressure, and the possibility to shift investment responsibility to private sector has played a crucial role in the increased acceptance of private-sector involvement in infrastructure development. PPP was then a solution to better infrastructure provision. However, since overthrowing its dictator in 2011 and kicking off the Arab Spring pro-democracy wave, Tunisia has been buffeted by economic turmoil and social uprisings. Today, after the first parliamentary election of October 26, 2014, the outlook seems however positive as the country begins its transition toward a new democracy.

This analysis identified the economic and social environment as a key success factor for the construction and management of a PPP infrastructure in Tunisia after its Jasmine Revolution. This finding has a pragmatic value. Indeed, 3 years after the uprisings in Tunisia, economic and social environments remain unsteady and hindered the achievement of Enfidha Airport. This assessment leads us logically to question the other PPP achievements. Today, Tunisia should capitalize the hope of change and democracy brought 
by the Arab Spring in order to generate increased opportunities for PPP infrastructure projects in the country. Consequently, the key capacity challenge that the new government face includes the capacity to settle down the sociopolitical climate to reassure and attract local and foreign investors.

The MENA region may become a major international center of economic development if it successfully transitions to democracy. Numerous opportunities are available in this region (Orsi, 2011). The MENA population is due to significantly increase and that growth will require important investments in new infrastructure. An estimated amount of 500 billion is to be spent in the region by 2020 on infrastructure development through PPPs (Roudi-Fahimi \& Kent, 2007). Modifications of the national political and social issues should be carried in advance in order to facilitate PPPs.

\section{References}

African Development Bank. (2011). The revolution in Tunisia: Economic challenges and prospects. Retrieved from http://www.afdb.org/fileadmin/uploads/afdb/ Documents/Publications/North\%20Africa\%20Quaterly\% 20 Analytical\%20 Anglais $\% 20$ ok_North\%20Africa\% 20Quaterly\%20Analytical.pdf.

African Development Fund. (2008). Tunisia, TunisiaMonastir and Enfidha airports project environmental and social impact assessment. ESIA study, Private Sector department infrastructure and PPP division.

Allan, J. R. (1999). Public-private partnerships: A review of literature and practice (Public Policy Paper $\mathrm{N}^{\circ} 4$ ). Saskatchewan Institute of Public Policy, University of Regina.

Araújo, S., \& Sutherland, D. (2010). Public-private partnerships and investment in infrastructure (OECD Economics Department Working Paper No. 803). Paris, France: OECD Publishing.

Arrow, K. J. (1985). Informational Structure of the Firm. The American Economic Review, 75(2), 303-307.

Ayee, J. R. A. (2005). Public sector management in Africa (Economic Research Working Paper No82). Tunis, Tunisia: African Development Bank, pp. 1-60.

Boyfield, K. (1992). Private sector funding of public sector infrastructure. Public Money \& Management, 12(2), 41-46. doi:10.1080/09540969209387708

Brown, A., Orr, A., \& Luo, J. (2006). The suitability of Public Private Partnerships in the provision of sustainable housing in China. World Review of Entrepreneurship, Management and Sustainable Development, 2(1), 101-125.

Buchanan, J., \& Tolluck, G. (1962). The calculus of consent. Ann Arbor, MI: University of Michigan Press.

Chédor, S., Teulon, F., \& Veil-Zarda, C. (2011). Les partenariats public-privé en Afrique du Nord: Le cas de la gestion de l'eau. Maghreb-Machrek, 209(3), 9-26.

Cohen, M. D., March, J. G., \& Olsen, J. P. (1972). A garbage can model of organizational choice. Administrative Science Quarterly, 17(1), 1-25.
Deloitte Research. (2006). Closing the infrastructure gap: The role of public-private partnerships. London, UK: Deloitte Development LLP.

Dilami, M., \& Klein, M. (1997). Government support to private infrastructure projects in emerging markets. In T. Irwin (Ed.), World Bank Latin American and Caribbean studies viewpoints: Dealing with public risk in private infrastructure (pp. 21-42). Washington, DC: World Bank.

Downs, A. (1967). Inside bureaucracy. Boston, MA: Little, Brown.

Esposito, M. C. (2010). La Politique des partenariats publicprivé: Une approche bipartisane en évolution. Observatoire De La Société Britannique, pp. 51-68.

Estache, A., Guasch, J.-L., Iimi, A., \& Trujillo, L. (2009). Multidimensionality and renegotiation: Evidence from transport-sector public-private-partnership transactions in Latin America. Review of Industrial Organization, 35(1/2), 41-71. doi:10.1007/s11151-009-9225-0

Farazmand, A. (2004). Sound governance in the age of globalization: A conceptual framework. In Farazmand (Ed.), Sound governance: Policy and administration innovation (pp. 1-24). Westport, CT: Praeger.

Farazmand, A. (1999). Building partnerships for governance. Background paper presented at the UN-sponsored World Congress on Governance, Manila, The Philippines, May 31- June 4.

Finnerty, J. D. (1996). Project financing: Asset-based financial engineering. New York, NY: John Wiley \& Sons.

Grimsey, D., \& Lewis, M. (2002). Evaluating the risks of public private partnerships for infrastructure projects. International Journal of Project Management, 20, 107-118 doi:10.1016/S0263-7863(00)00040-5

IFC. (2008, April). Summary of proposed investment, INT'L FIN. CORP. Retrieved from http://www.ifc.org/ifcext/spi website1.nsf/0/9F0D31A0EFB9FC06852576BA000E2B83 (discussingthe TAV Tunisie Project).

Jones, I., Zamani, H., \& Reehal, R. (1996). Financing models for new transport infrastructure. Luxembourg: OPEC.

Kettl, D. F., \& Milward, H. B. (Eds.). (1996). The state of public management. Baltimore, MD: Johns Hopkins University Press.

Kirkpatrick, I., \& Lucio, M. (1996). Introduction: The contract state and the future of public management. Public Administration, 74(1), 1-8. doi:10.1111/padm.1996.74. issue-1

Klijn, E.-H., \& Teisman, G. R. (2002). Institutional and strategic barriers to public-private partnership: An analysis of Dutch cases. Paper presented at the British Academy of Management Conference, 9-11 September, Middlesex University, London.

Li, B., Akintoye, A., Edwards, P. J., \& Hardcastle, C. (2005). Critical success factors for PPP/PFI projects in the UK construction industry. Construction Management and Economics, 23(5), 459-471. doi:10.1080/ 01446190500041537

Marty, F. (2008). Les enjeux économiques et industriels liés au recours aux partenariats public-privé dans le domaine spatial Une application: Le contrat de Private Finance Initiative britannique Skynet V.

Marty, F., \& Voisin, A. (2006). L'évolution des montages financiers des PFI britanniques: La montée des risques. Revue Française de Finances Publiques, 94, 107-120. 
Mohammed, B.-M. (2010). Financing water services in the Arab countries public private participation, PPP, The Jordanian Experience, Private Sector Involvement in Water Infrastructure in Lebanon. Beirut, Lebanon: The Arab Countries Water Utilities Association (ACWUA). Retrieved from http://www.inbonews.org/IMG/pdf/Financing_Water_ in_the_Arab_Countries_Beirut89_3_2010.pdf

Mohyeldin, A. (2011, January 20). Suicide sparked Tunisia revolution. Al Jazeera English, Opinion. Retrieved from http://english.aljazeera.net/indepth/opinion/2010/12/ 20101231161958792947.html

Niskanen, W. (1971). Bureaucracy and representative government. Chicago, IL: Aldine-Atherton.

OECD. (2008). Public-private partnerships: In pursuit of risk sharing and value for money. Paris, France: OECD.

OECD. (2009). Bridging state capacity gaps in situations of fragility, partnership for democratic development. Paris, France: OECD.

Orsi, S. D. (2011). Arab spring brings winds of change to the Maghreb and MENA region: Does that spell opportunity for infrastructure development and project finance? Richmond Journal of Global Law and Business, 11, 77-124.

Osborne, D., \& Gaebler, T. (1992). Reinventing government: How the entrepreneurial spirit is transforming government. Reading, MA: Addison Wesley Public Comp.

Osborne, S. (Ed.). (2000). Public-private partnerships: Theory and practice in international perspective. London, UK: Routledge.

Qiao, L., Wang, S. Q., Tiong, R. L. K., \& Chan, T.-S. (2001). Framework for critical success factors of BOT projects in China. The Journal of Structured Finance, 7(1), 53-61. doi:10.3905/jsf.2001.320244

Roudi-Fahimi, F., \& Kent, M. (2007). Challenges and opportunities: The population of the Middle East and North Africa. Population Reference Bureau, 62(2), 24.

Sadiki, L. (2010, December 27). Tunisia: The battle of Sidi Bouzid. Al Jazeera English, Opinion. Retrieved from http:// english.aljazeera.net/indepth/opinion/2010/12/ 20101227142811755739.html

Sengupta, U. (2006). Government intervention and publicprivate partnerships in housing delivery in Kolkata. Habitat International, 30(3), 448-461. doi:10.1016/j. habitatint.2004.12.002
Stein, S. W. (1995). Construction Financing and BOT projects. International Business Lawyer. International Bar Association, 23(4), 173-180.

Timeline: Tunisia's uprising. (2011, January 23). Al Jazeera English, Africa. Retrieved from http://english.aljazeera.net/ indepth/spotlight/tunisia/2011/01/201114142223827361. html

Tunisian Ministry of Tourism. (2014). Retrieved from http:// www.tourisme.gov.tn/index.php?id=206

Tunisian Ministry of Transportation. (2011). Retrieved from http://www.transport.tn/index.php?option=com_content\& view $=$ article\&id $=104 \&$ Itemid $=107 \&$ lang $=$ fr

UNEVOC Centers. (2006). Good practices in public-private partnership and labour market orientation in TVET in the $M E N A$ region. A study tour for UNVECO centers. Cairo, Egypt.

Vining, A. R., \& Boardman, A. E. (2008). Public-private partnerships: Eight rules for governments. Public Works Management \& Policy, 13(2), 149-161 doi:10.1177/ $1087724 X 08323843$

Williamson, O. (1975). Markets and hierarchies. Analysis and antitrust implications: A study in the economics of internal organization. New York, NY: Free Press.

Williamson, O. (1985). The economic institutions of capitalism. Firms, markets, relational contracting. New York, NY: Free Press.

World Bank (The). (1994). World development report: Infrastructure for development. Washington, DC: Author.

World Bank (The). (2014). Tunisia overview. Retrieved from http://www.worldbank.org/en/country/tunisia/overview

World Bank. (2007). Private participation in infrastructure database. Singapore: Author. Retrieved from http://ppi. worldbank.org

World Bank. (2008). Annual Report: Helping to eliminate poverty and achieve sustainable development through public-private partnerships in infrastructure. Public-Private Infrastructure Advisory Facility (PPIAF). Washington, DC: World Bank.

World Bank. (2011). PPIAF assistance in Tunisia. PublicPrivate Infrastructure Advisory Facility (PPIAF). Washington, DC: World Bank. 